\title{
Balanço Social dos Bancos/Febraban: uma análise da evolução da responsabilidade social empresarial (RSE)
}

\author{
Elvira Cruvinel Ferreira Ventura *
}

\begin{abstract}
Resumo
0 objetivo do artigo é estabelecer um panorama da evolução da responsabilidade social empresarial (RSE) no setor bancário, por meio da análise dos balanços sociais dos bancos, de onze anos consecutivos, publicados pela Federação Brasileira de Bancos (Febraban), associação representativa do setor. A análise dos balanços sociais dos Bancos/Febraban evidencia como a prática da RSE e o tratamento dispensado à questão vão sendo modificados ao longo dos anos, revelando a crescente institucionalização do fenômeno na sociedade brasileira. Nesse sentido, de um relatório relativamente simples em 1993, o Balanço Social dos Bancos/Febraban passa a um elevado nível de sofisticação, incorporando, a partir de 2002, as dimensões econômica, ambiental e social das atividades, produtos e serviços bancários. $\mathrm{Na}$ medida em que o fenômeno da RSE vai ganhando amplitude e destaque no Brasil, o Balanço Social dos Bancos/Febraban vai sendo refinado de modo a espelhar os novos padrões exigidos pela sociedade, numa reorientação das ações com vistas à aquisição de legitimidade social.
\end{abstract}

Palavras-chave.: Cadma; Balanço Social; Responsabilidade Social Empresarial; Bancos.

\begin{abstract}
The objective of the paper is to establish a panorama of the evolution of the enterprise's social responsibility - RSE in the banking sector, by means of the analysis of the Social Balance of the Banks. The social balance of a period of eleven years consecutive, published for a representative association of the sector, the Brazilian Federacy of the Associations of Banks Febraban, were analysed. The social balance is considered a multiplying structural arrangement of the RSE, besides disclosing the given treatment to the question. The analysis of the data shows that social responsability was modified along the years (as the practical one of the social responsibility goes if modifying to the long one of the years) - from a relatively simple report in 1993, it reaches to one high level of sophistication, incorporating the economic, environmental and social dimensions of its activities, products and services, in 2002. Thus, while the subject goes gaining amplitude and prominence in Brazil, the social balance goes refining and being modified in order to reflect the new standards demanded for the society, in a reorientation of the actions aiming to acquire greater social legitimacy.
\end{abstract}

Key words: Cadma; Social Balance; Social Responsability; Banks.

\footnotetext{
* Doutora em Administração pela Escola Brasileira de Administração Pública e de Empresas da Fundação Getulio Vargas (EBAPE/FGV). Analista no Departamento de Organização do Sististema Financeiro (Deof) no Banco do Central do Brasil. E-mail: elvira.ventura@ bcb.gov.br. Endereço: Avenida Presidente Vargas, 730 - 190 andar. CEP : 20071-900 - Rio de Janeiro - RJ.

Artigo recebido em maio de 2005 e aceito para publicação em julho de 2005.
} 


\section{Introdução}

Diferentes motivações e interesses podem levar empresas a serem socialmente responsáveis. Estes podem variar desde a percepção da responsabilidade social como investimento até sua percepção como uma questão de cidadania. Se a idéia se aproxima mais da "cidadania", o vocabulário tende a ser civil-político e o foco deslocase para a exigência de co-responsabilidade e de participação. Se vier traduzida na categoria "investimento", traz consigo uma ênfase econômica (PAULA e ROHDEN, 1998).

Embora já amplamente difundida, a prática da RSE ainda encontra obstáculos em sua operacionalização, pela dificuldade de definição do próprio conceito. Outro obstáculo para maior difusão da prática da RSE é o argumento de que o social é imensurável. O balanço social surge, então, com a promessa de uma solução para a questão, contabilizando as ações e tornando-as de domínio público. É, então, um arranjo estrutural criado com vistas a definir um problema e, ao mesmo tempo, propor sua solução.

Principalmente depois da campanha em prol da divulgação do balanço social, lançada pelo sociólogo Herbert de Souza, em 1997, muitas empresas no Brasil passaram a preparar e a divulgar esses relatórios. De lá para cá, também, é crescente o número de organizações que passaram a discutir a RSE de forma mais sistematizada. Nesse contexto, as organizações bancárias brasileiras têm se inserido na discussão e difusão da RSE de forma veemente. A Federação Brasileira de $\operatorname{Bancos}^{1}$ (Febraban) pode ser considerada pioneira na publicação de balanços sociais, já o fazendo, para todo o setor bancário, desde 1993.

O objetivo deste artigo é estabelecer um panorama da evolução da RSE no setor bancário, por meio da análise dos Balanços Sociais dos Bancos/Febraban, de onze anos consecutivos. Em nosso entendimento, esses relatórios refletem o processo de institucionalização do fenômeno da RSE na sociedade, de forma geral, e no setor bancário, de forma específica. Na medida em que o conceito e a prática da RSE vão sendo delineados e também modificados, o balanço social vai sendo adaptado, espelhando as transformações organizacionais e sociais envolvidas.

Em relação aos aspectos metodológicos da pesquisa, tratou-se basicamente de uma análise documental, especificamente dos Balanços Sociais dos Bancos/Febraban. ${ }^{2}$ Além disso, em janeiro de 2004, realizamos uma entrevista com representantes da Febraban (diretora da Comissão de Responsabilidade Social, superintendente técnico e assessora de Responsabilidade Social), para compreensão do contexto de surgimento e evolução da RSE e do balanço social no setor bancário. Em agosto de 2004, realizamos outra entrevista com a diretora da Comissão de Responsabilidade Social, para atualização das informações.

Cabe salientar que este artigo, após apresentação no I Congresso Acadêmico sobre Meio Ambiente e Desenvolvimento (CADMA, 2004), sofreu atualização de dados, visando principalmente à incorporação da análise do Balanço Social dos Bancos/Febraban referente ao ano de 2003.

\section{Responsabilidade social das empresas (RSE)}

Na discussão sobre a RSE predomina a linha que explica o fenômeno como algo intrinsecamente positivo para as organizações e para a sociedade, apontando as motivações e benefícios auferidos com sua adoção e aprofundando-se na operacionalização do conceito. A literatura tem exaltado a responsabilidade social como um bom caminho para as organizações modernas e também para a resolução de problemas sociais.

\footnotetext{
${ }^{1}$ Até o ano de 2004, o nome era Federação Brasileira das Associações de Bancos.

${ }^{2}$ Um exemplar de cada ano do Balanço Social dos Bancos foi cedido pela Febraban para a pesquisa. Em sua home-page constam os balanços sociais de 2001, 2002 e 2003. Disponível em: <http:// www.febraban.org.br>. Acesso em: 10 fev.2005.
} 
Menos dominante é a linha que procura analisar criticamente a RSE, mostrando que, embora positiva sob muitos aspectos, não é uma panacéia para as empresas e muito menos para a sociedade. Assim, tanto na literatura, como no que Cheibub e Locke (2002) denominam "movimento pela responsabilidade social das empresas", coexistem definições e explicações. O estudo desenvolvido por Cappellin et al (2002) conclui que,

se por um lado, a problemática da responsabilidade social das empresas está assumindo uma importância crescente, envolvendo em importantes discussões diversos setores da sociedade, por outro, aparece como criadora de conceitos, metodologias, estratégias de ação, cujo conteúdo ainda é claramente "disputado" (CAPPELLIN et al, 2002, p.273).

E nessa disputa pela configuração do conceito, um grande volume de publicações, cursos e consultorias especializadas vão surgindo para tratar do tema - indicando a cada dia maiores interesses envolvidos em sua disseminação, implicando sua crescente institucionalização.

Na visão de Cheibub e Locke (2002), o que se verifica é que, nas análises produzidas, muitos aspectos da RSE são negligenciados. Para eles, o principal ponto é que as ações de RSE não têm consequiências somente para a própria empresa ou para seus beneficiários diretos, mas para a sociedade como um todo, pois podem influir na distribuição de poder político na própria sociedade. Deve-se considerar no debate, então, a dimensão pública/política dessas ações (CHEIBUB e LOCKE, 2002).

Na visão de Ventura (2003), o movimento pela RSE parece surgir como resultado da crítica à forma pela qual as empresas se relacionam com a sociedade, pouco beneficiando-a ou até causando-lhe danos. Em resposta, na institucionalização do movimento, são criados institutos para lidar com o assunto - de forma isomórfica às empresas -, são instituídas certificações na área social (como a SA8000 e AA1000), balanços, selos, concursos; ou seja, todo um conjunto de regras e convenções, dispositivos para categorizar e classificar as empresas em relação a seu comportamento socialmente responsável, onde são exigidos e valorizados aspectos que, em última instância, os próprios capitalistas elegem (VENTURA, 2003).

Todavia, o estabelecimento de fronteiras na caracterização de uma ação como de responsabilidade social é assunto complexo. Pode-se dizer que a RSE transita por dois níveis. No nível interno, pela sua relação com a comunidade interna - funcionários, sócios e acionistas. ${ }^{3}$ No nível externo, envolve o meio ambiente, clientes, fornecedores, a comunidade onde se insere e aquelas que atinge através de seus produtos e serviços, ou pelo efeito destes. ${ }^{4}$

Ressalvados esses aspectos, pode-se acrescentar que, segundo Motta (1981), a operacionalização da RSE exige a explicitação de objetivos que, por sua vez, deve ser precedida da reorientação dos valores da empresa e de uma certa estruturação organizacional. Assim, visando obter legitimidade perante a sociedade, a empresa passa a absorver valores que a sociedade revela e valoriza, incluindo-os em seus propósitos básicos e em seus planos estratégicos, de modo consiste com os dela.

Nesse sentido, o balanço social é um arranjo estrutural que, criado com a finalidade de demonstrar os benefícios auferidos com a adoção da prática da RSE, passou a espelhar também essa reorientação de valores da empresa, buscando a legitimidade da organização e, ao mesmo tempo, institucionalizando o fenômeno da RSE.

\footnotetext{
${ }^{3}$ No nível interno, a literatura sobre o assunto e a prática empresarial têm exaltado aspectos relacionados, principalmente, à qualidade de suas relações humanas, como, por exemplo, a disseminação de uma cultura participativa, processos decisórios e fluxo de comunicação transparentes, um clima organizacional saudável, além, é claro, de uma adequada política de compensação e condições de trabalho, no que diz respeito à saúde ocupacional - medicina, higiene e segurança do trabalho.

${ }^{4}$ No nível externo, primeiro de tudo, existe a relação da empresa com a comunidade local. Esta pode se traduzir em filantropia ou em projetos sociais em parceria.
} 


\section{Balanço social}

Como resposta às pressões sociais, a auditoria social, a partir dos anos 1940, teve como finalidade identificar e quantificar componentes da responsabilidade social, numa tentativa de medição para verificação da validade das ações (BOWEN, 1953). Bowen, já em 1953, sugere uma auditoria social em oito áreas: preços, salários, pesquisa e desenvolvimento, propaganda, relações públicas, relações humanas, relações comunitárias e estabilidade de emprego.

O conceito de auditoria social evoluiu para o conceito de balanço social, que seria a expressão da responsabilidade social das organizações e tornaria claro ao público consumidor, e à sociedade em geral, quais as ações organizacionais que contribuem para a melhoria nas condições de vida, tanto de uma perspectiva interna quanto externa à empresa. Segundo o Instituto Brasileiro de Análises Sociais e Econômicas (Ibase), um marco na história dos balanços sociais foi 1972, ano em que a empresa Singer, na França, fez o primeiro balanço social da história das empresas.

Para Souza (1997), o balanço social é uma demonstração responsável de investimentos sociais realizados pelas empresas. Para Torres (1998), a função principal do balanço social é tornar pública a responsabilidade social da empresa.

A proposta de tornar a empresa mais transparente através da publicação do balanço social, todavia, é questionável, uma vez que os dados podem ser manipulados a fim de legitimar a responsabilidade social da empresa perante a sociedade. Outro debate é sobre a obrigatoriedade do balanço social, como é o caso da França, onde, desde 1977' todas as empresas com mais de 700 funcionários devem publicá-lo. Posteriormente, esse número caiu para 300 funcionários, aumentando o escopo de empresas que devem publicar o balanço social naquele país.

No Brasil, na década de 1980, a Fundação Instituto de Desenvolvimento Empresarial e Social (Fides) chegou a elaborar um modelo de balanço social. Porém, só a partir do início dos anos 1990 é que algumas poucas empresas passaram a divulgar sistematicamente em balanços e relatórios sociais as ações realizadas em relação à comunidade, ao meio ambiente e ao seu próprio corpo de funcionários. O balanço social da Nitrofértil, empresa estatal situada na Bahia, em 1984, é considerado o primeiro do Brasil. O balanço social do Banespa, organização do setor bancário, realizado em 1992, compõe a lista das empresas precursoras em balanços sociais no Brasil.

A idéia do balanço social, porém, ganhou força no Brasil a partir de 1997, quando o sociólogo Herbert de Souza, o Betinho, lançou uma campanha pela divulgação voluntária do balanço social. Com o apoio e a participação de lideranças empresariais, a campanha tornou a prática mais disseminada. Em 1998, o Ibase lança um selo para empresas que anualmente publicam seu balanço social de acordo com o modelo desenvolvido por aquele instituto, o que se configura como mais um elemento que alavanca a publicação do relatório e também, por outro lado, da prática da RSE no Brasil.

Também impulsionador das práticas de RSE, em 1998, foi criado o Instituto Ethos de Empresas e Responsabilidade Social, uma associação sem fins lucrativos destinada a fomentar o desenvolvimento da cidadania empresarial, sensibilizando e mobilizando a classe, a fim de assumir a promoção do desenvolvimento econômico com responsabilidade social. O Instituto Ethos teve e tem papel relevante na disseminação do balanço social no meio empresarial brasileiro, de forma geral.

Especificamente no setor bancário, a Febraban, como entidade representativa do setor, também tem papel importante na institucionalização da RSE. Para melhor compreensão desse movimento no setor bancário, necessário se faz - ao conhecer a história de suas organizações e a natureza de suas atividades - buscar também o nascedouro do discurso da RSE. É o que objetiva a próxima seção. 


\section{Os bancos no Brasil}

A história dos bancos no Brasil é também um reflexo de seu desenvolvimento econômico. Quando da chegada de Dom João VI ao Brasil, em 1808, é criado o primeiro banco no Brasil, o Banco do Brasil. ${ }^{5}$ Mas, apesar de muitos benefícios concedidos ao banco, levou-se mais de um ano para a venda do número de ações necessárias para o início das atividades, o que reflete o reduzido nível de atividade econômica. Em Carta Régia, em 1812, o príncipe regente apelava aos habitantes do reino - capitalistas, empresários e funcionários públicos - para contribuírem para o desenvolvimento do banco através da compra de ações, prometendo-lhes deferência especial. Entretanto, o Banco do Brasil teve suas atividades encerradas em 1829, tendo suas obrigações sido convertidas em obrigações do governo. ${ }^{6}$

Com a Independência do Brasil, em 1822, e com o incremento das atividades produtivas e comerciais, vários bancos de depósitos e descontos foram sendo criados no país. Em 1864, houve séria crise bancária, quebrando os famosos banqueiros A. J. Souto \& Cia. Daquela época até a Proclamação da República, em 1889, três problemas afetaram a estrutura econômica do país: a Guerra do Paraguai (1865-70), a seca no Nordeste - que vitimou 300 mil pessoas e exigiu dinheiro público - e a Abolição da Escravatura, em 1888, que modificou a estrutura econômica, inclusive, pela perda de metade da safra, dado o abandono das fazendas pelos escravos libertos. Com a concessão da faculdade emissora a três bancos, desencadeou-se o chamado Encilhamento uma época difícil, na qual cada dia mais se fazia necessário o papel-moeda para pagamento aos escravos libertos, para operação de empresas e para alimentar a especulação que se formou. A República concedeu essa faculdade a outros bancos, até que, verificando-se suas consequiências inflacionárias, foi suspensa em 1898. O Banco da República ${ }^{7}$ passa à administração governamental, dado um depósito de um milhão de libras esterlinas efetuado. Em 1905, tinha funções de banco central e reassumiu a denominação de Banco do Brasil.

A partir de 1929, até 1939, foram feitas várias tentativas de criação de um moderno banco central no Brasil. Em 1945, foi criada a Superintendência da Moeda e do Crédito (Sumoc), que recebeu as funções de exercer o controle sobre o mercado financeiro, bem como assentar as bases para o surgimento de um futuro banco central. Dada a composição de sua administração, tornou-se cada vez mais um conselho econômico nacional do mais alto nível. Mas o que era para ser um curto período de transição, por inúmeras razões, levou vinte anos para acontecer.

Com a promulgação da Lei $\mathrm{n}^{\circ}$ 4.595, em 31-12-1964, denominada Lei da Reforma Bancária, foram estabelecidas as diretrizes, normas e características de funcionamento das instituições no Sistema Financeiro Nacional

\footnotetext{
5 Segundo Peláez e Suzigan (1976), de acordo com historiadores do Banco do Brasil - e também pelas razões oficiais no ato legislativo -, do lado econômico, o estabelecimento do banco resultou da necessidade de saldos em dinheiro devido à liberdade de comércio exterior e às novas despesas governamentais causadas pela guerra no sul do país e pelas expedições. No ato salientou-se ainda que o Brasil precisaria de instituições que pudessem mobilizar as poupanças e o capital; o que aponta para uma idéia rudimentar de intermediação financeira. Os fatores não-econômicos relacionam-se à filosofia econômica que seguia o Conde de Linhares, que teve a idéia do banco, numa tentativa de alcançar a unidade nacional através do estabelecimento de grandes instituições bancárias.

${ }^{6}$ Segundo Souza Franco (1848 apud PELÁEZ e SUZIGAN, 1976, p.56-57), historiadores econômicos atribuem a falência do primeiro Banco do Brasil à sua interligação com o governo, que se converteu em fornecedor de recursos para pagar as despesas governamentais. Mas outro fator que deve ser considerado, asseveram os autores, talvez o maior causador a falência, foram as políticas monetárias inadequadas, como a cunhagem de grandes quantidades de moeda de cobre e a autorização para emissões ilimitadas de papel-moeda. Em sua análise sobre a estrutura monetária do Brasil à época da Independência, Souza Franco (apud PELÁEZ e SUZIGAN, 1976) chama a atenção para a falta de uma mentalidade que pudesse compreender as funções de intermediação executadas pelas instituições bancárias. Mas somente no período 1840-50 houve um debate nacional sobre a necessidade de instituições monetárias e o crescimento e a diversificação dos mercados monetários e de capitais.
}

7 Em janeiro de 1890 foi autorizado a funcionar o Banco dos Estados Unidos do Brasil, que, fundido com o Banco Nacional, em 1890 , passou a se chamar Banco da República dos Estados Unidos do Brasil. A ele foi outorgado o poder exclusivo de emitir notas com circulação em todo o território nacional, em quantidade igual ao triplo do seu lastro-ouro. Em 1892 fundiu-se esse banco, novamente, com o Banco do Brasil, passando à denominação de Banco da República do Brasil. Em 1893, perdeu a faculdade emissora. Em 1896, o governo assume a responsabilidade das emissões bancárias. 
(SFN), que passa a ser constituído pelo Conselho Monetário Nacional (CMN), pelo Banco Central (Bacen), pelo Banco do Brasil (BB), pelo Banco Nacional de Desenvolvimento Econômico e Social (BNDES) e pelas demais instituições financeiras públicas e privadas do país.

De acordo com a Lei $\mathrm{n}^{0}$ 4.595, ainda vigente, são consideradas instituições financeiras as pessoas jurídicas públicas ou privadas que tenham como atividade principal ou acessória a coleta, intermediação ou aplicação de recursos financeiros próprios ou de terceiros, em moeda nacional ou estrangeira, e a custódia de valor de propriedade de terceiros.

Em análise efetuada na década de 1970, quando os efeitos da Lei no 4.595 se faziam sentir, Calicchio (1972), analisando o que chamou o Novo Banco, afirma: "notamos facilmente a nova amplitude de seus serviços e o aumento de sua responsabilidade para a economia nacional [...]". Ainda segundo o autor, os bancos sentiram em curto espaço de tempo a

[...] necessidade imperiosa de adaptação às modificações que se processaram na vida da comunidade [...] Em uma estrutura estacionada no tempo, porém sempre cônscia de sua responsabilidade social como geradora de desenvolvimento, do bem-estar econômico da comunidade, e fomentadora básica desta enorme sociedade de consumo [...] surgiu nos horizontes a obrigatoriedade da nova imagem [...] Ativo em sua responsabilidade maior quer seja sua função social. Não mais o Templo Sagrado onde somente os poderosos se atreviam a entrar, mas uma instituição plenamente democrática. Existindo para atender aos que nela buscam recursos para iniciar empreendimentos, manter negociações, financiar o desenvolvimento, superar obstáculos, orientar a poupança, enfim, para assistir cada vez em maior dimensão o Cliente, fator preponderante à sua sobrevivência. (CALICCHIO, 1972, p.139-145)

Observa-se na literatura, pela primeira vez, então, menção expressa à responsabilidade social dos bancos. Tratase de um novo posicionamento dos bancos perante a sociedade, compelidos por mudanças sociais e de mercado.

Após a lei da Reforma Bancária, muitas modificações ocorreram no SFN, sendo incorporados novos agentes reguladores e organizações, indicando um alargamento de seu escopo (estrutura do SFN disponível em: <www.bcb.gov.br>).

Segundo Troster (2005), a estabilização da moeda a partir de 1994, o saneamento do sistema financeiro, a abertura aos bancos estrangeiros, a privatização de bancos estatais, o fluxo crescente de capitais internacionais, o impacto das crises externas e as exigências regulatórias são alguns dos fatores que influenciaram uma mudança sem paralelos na história bancária brasileira. Em números redondos, cerca de metade dos bancos existentes antes da estabilização monetária mudaram de controle ou deixaram de existir (TROSTER, 2005).

Nesse sentido, Assaf Neto (2001) destaca uma característica da estrutura do SFN, que são os conglomerados financeiros. Os conglomerados foram criados em função da política de concentração bancária por meio, principalmente, de fusões e aquisições. Esses conglomerados, segundo o autor, por meio das diversas instituições que estão sob seu controle, costumam atuar nos diversos segmentos financeiros do mercado, limitando bastante a atuação de instituições independentes (ASSAF NETO, 2001). 
Tabela 1

Os 20 maiores bancos e sua participação no Sistema Financeiro Nacional (SFN)

(Data-base: 31-12-2004)

\begin{tabular}{|c|c|c|c|c|c|c|c|}
\hline \multirow{2}{*}{$\begin{array}{l}\text { Banco } \\
\text { (1) }\end{array}$} & \multirow{2}{*}{$\begin{array}{l}\mathrm{TC} \\
(2)\end{array}$} & \multicolumn{4}{|c|}{ Em R\$ mil } & \multirow{2}{*}{$\begin{array}{c}\text { Número de } \\
\text { Funcionários } \\
\text { (4) }\end{array}$} & \multirow{2}{*}{$\begin{array}{c}\text { Número de } \\
\text { Agências } \\
\text { (4) }\end{array}$} \\
\hline & & Ativo total & $\begin{array}{l}\text { Patrimônio } \\
\text { líquido }\end{array}$ & $\begin{array}{l}\text { Lucro } \\
\text { líquido }\end{array}$ & Depósito total & & \\
\hline $\mathrm{BB}(5)$ & 1 & 239.014 .143 & 14.105 .696 & 1.603 .254 & 115.531 .842 & 106.061 & 3.783 \\
\hline$C E F$ & 1 & 147.786 .559 & 6.663 .640 & 796.057 & 91.772 .694 & 100.164 & 2.135 \\
\hline Bradesco & 3 & 148.207 .637 & 15.221 .289 & 1.973 .854 & 68.687 .387 & 68.155 & 3.011 \\
\hline Itaú & 3 & 123.443 .368 & 16.015 .523 & 3.078 .774 & 42.224 .637 & 48.532 & 2.205 \\
\hline Unibanco & 5 & 72.928 .818 & 8.334 .908 & 724.781 & 33.992 .812 & 23.488 & 918 \\
\hline Santander/Banespa & 4 & 66.548 .096 & 8.485 .610 & 824.580 & 22.912 .874 & 21.540 & 1.028 \\
\hline ABN AMRO & 4 & 59.150 .578 & 8.927 .989 & 140.787 & 32.363 .359 & 28.229 & 1.111 \\
\hline Safra & 3 & 40.841 .868 & 3.635 .269 & 352.631 & 9.984 .685 & 4.721 & 86 \\
\hline HSBC & 4 & 34.374 .797 & 2.674 .790 & 331.640 & 23.062 .877 & 25.968 & 926 \\
\hline Nossa Caixa & 2 & 31.251 .866 & 2.163 .340 & 212.815 & 22.014 .899 & 14.125 & 506 \\
\hline Votorantim & 3 & 36.586 .675 & 3.283 .987 & 398.348 & 13.079 .040 & 360 & 4 \\
\hline Citibank & 4 & 21.957 .104 & 2.904 .548 & -266.113 & 6.015 .969 & 2.505 & 53 \\
\hline BankBoston & 4 & 21.414 .563 & 2.917 .297 & -52.889 & 3.086 .317 & 3.700 & 60 \\
\hline $\mathrm{BNB}$ & 1 & 13.167 .413 & 1.340 .386 & 63.897 & 2.711 .629 & 8.725 & 181 \\
\hline Banrisul & 2 & 12.202 .699 & 1.025 .833 & 190.614 & 7.731 .176 & 10.978 & 386 \\
\hline Crédit Suisse & 4 & 13.570 .750 & 702.864 & -27.628 & 2.383 .117 & 10 & 2 \\
\hline Alfa & 3 & 7.778 .449 & 1.155 .837 & 70.422 & 2.366 .368 & 849 & 9 \\
\hline JP Morgan Chase & 4 & 6.585 .016 & 1.324 .468 & 62.418 & 1.230 .503 & 305 & 5 \\
\hline Pactual & 5 & 8.470 .905 & 613.899 & 99.824 & 1.027 .781 & 417 & 4 \\
\hline Santos (5) & 3 & 6.369 .707 & 559.747 & -44.773 & 1.863 .873 & 256 & 4 \\
\hline Total 20 & & 1.111 .651 .011 & 102.056 .920 & 10.533 .293 & 504.043 .839 & & \\
\hline Total SFN (3) & & 1.450 .625 .745 & 146.903 .877 & 12.689 .279 & 572.124 .524 & & \\
\hline Total 20 e SFN (\%) & & $76,63 \%$ & $69,47 \%$ & $83,01 \%$ & $88,15 \%$ & & \\
\hline
\end{tabular}

(1) Bancos: equivalem aos conceitos de conglomerados bancários (conjunto de instituições financeiras que consolidam seus demonstrativos contábeis) e instituições independentes;

(2) TC (Tipo de controle): identifica a origem do controle de capital dos conglomerados bancários ou das instituições independentes: 1público federal, 2-público estadual, 3-privado nacional, 4-privado controle estrangeiro e 5-privado participação estrangeira.

(3) restrito às instituições autorizadas a funcionar pelo Banco Central do Brasil, exceto as administradoras de consórcios - agrupadas ou não em conglomerados;

(4) as informações sobre número de funcionários (pessoal que trabalha na instituição, sejam efetivos, contratados, terceirizados, estagiários e outros) e de agências em funcionamento (quantidade de sede e agências ativas), referem-se exclusivamente às instituições bancárias (não incluindo as instituições não-bancárias, no caso de conglomerados).

(5) banco sob intervenção que descumpriu o prazo de entrega de documentos contábeis (out. 2004).

Fonte: elaborado com base em Bacen (2005).

Na tabela 1 são apresentados os maiores conglomerados e instituições independentes no Brasil, evidenciando a concentração bancária- os 20 maiores totalizam cerca de $77 \%$ do ativo total e cerca de $70 \%$ do patrimônio líquido do SFN, em 31-12-2004.

Segundo Assaf Neto (2001), por meio do SFN viabiliza-se a relação entre agentes carentes de recursos para investimento e agentes capazes de gerar poupança e, conseqüientemente, em condições de financiar o crescimento da economia. Para o autor, o SFN pode ser entendido como um conjunto de instituições financeiras e instrumentos financeiros que visam, em última instância, transferir recursos dos agentes econômicos (pessoas, empresas, governos) superavitários para os deficitários. 


\section{Federação Brasileira de Bancos (Febraban)}

Consideramos a Febraban um ator-chave no processo de institucionalização da RSE no setor bancário. Fundada em 1967, é a principal entidade representativa do setor bancário brasileiro e, operando em âmbito nacional, conta com 129 associados - de um universo de 161 instituições bancárias, em 2003, o que representa mais de $97,46 \%$ do total de ativos e $94,19 \%$ do patrimônio líquido do sistema -, o que lhe fornece um potencial disseminador da RSE e do balanço social.

Assim como sua missão, ${ }^{8}$ os valores da Febraban - valorizar as pessoas; promover valores éticos, morais e legais; incentivar práticas de cidadania e responsabilidade social; defender o livre mercado e a livre concorrência; atuar com profissionalismo e transparência; e valorizar a diversidade - sinalizam uma cultura alinhada ao movimento pela RSE no Brasil. De fato, esse novo perfil da Febraban é recente, tendo sido definido no ano de 2002, quando também foi criada uma comissão específica para tratar da RSE.

Segundo Cappellin et al. (2002), no contexto global, os empresários recorrem sempre mais às suas entidades associativas e de representação, que se colocam como veículos de intermediação privilegiados nas relações entre os empresários, a sociedade e o Estado. De acordo com pesquisa realizada por Cappellin et al. (2002), com 56 representações empresariais, em 1999, as atitudes empresariais com relação à responsabilidade social iam desde o desconhecimento da problemática - ou simples desinteresse por esta - até a sua compreensão ou empenho intelectual e prático nessa direção. A Febraban aparece na análise dos resultados da referida pesquisa inserida na categoria de entidade que considera que a responsabilidade social "é uma opção pessoal". Estar nessa categoria indica o reconhecimento da importância e da pertinência das questões relativas ao tema, ainda que não se pretenda assumir um envolvimento direto como instituição, acreditando-se que, se esta assumisse a iniciativa de propor ou coordenar ações sociais da própria entidade, poderia ter o efeito de inibir ou atrapalhar as ações individuais já em curso (CAPPELLIN et al, 2002).

Todavia, antes que a RSE e também a publicação de balanços sociais se tornassem disseminados na sociedade, como hoje o são, a Febraban iniciou a preparação e divulgação de um balanço social específico para as organizações bancárias. Sendo um setor que necessita de credibilidade para funcionar bem, onde o ambiente institucional deve fortemente ser considerado e que, historicamente, apresenta altos lucros, particularmente numa década em que o setor estava sofrendo reestruturações - principalmente pela concentração bancária por meio de fusões e aquisições, o que implicou ajustes diversos, como as demissões, por exemplo -, o balanço social pode ser entendido como um arranjo estrutural utilizado também para a legitimação dos bancos perante a sociedade.

Além de outras ações, a Comissão de Responsabilidade Social investiu na qualidade do balanço social, no sentido de atualizá-lo com indicadores específicos para o setor. A comissão buscou, então, num primeiro momento, para o balanço social referente ao ano de 2002, adequar os princípios do Global Reporting Initiative (GRI) ${ }^{9}$ às instituições financeiras. No ano seguinte, em parceria com o Instituto Ethos, foram desenvolvidos indicadores específicos para instituições financeiras, de acordo com o modelo Ethos. Nessa trajetória, os indicadores uti-

${ }^{8}$ A missão da Febraban é representar seus associados, objetivando a melhoria contínua da eficiência do sistema financeiro e das suas relações com a sociedade, contribuindo assim para o desenvolvimento econômico e social do país.

${ }^{9}$ Trata-se de um guia que objetiva melhorar a qualidade, o rigor e a aplicabilidade dos relatórios de sustentabilidade. Foi lançado em 1997, como uma iniciativa conjunta da organização não-governamental Coalition for Environmentally Responsible Economies (Ceres) e do Programa das Nações Unidas para o Meio Ambiente (Pnuma). Conta com a participação de representantes da indústria, de grupos ativistas sem fins lucrativos, de órgãos contábeis, de organizações de investidores e de sindicatos, entre outros, que trabalham conjuntamente visando atingir um consenso sobre as diretrizes para relatórios que possam alcançar aceitação mundial. Busca, então, ser consensual e universal, oferecendo um padrão de relatórios de sustentabilidade. O primeiro conjunto de diretrizes para relatórios de sustentabilidade do GRI surgiu, preliminarmente, em 1999. Depois de incorporadas críticas, foi lançado efetivamente em junho de 2000. O relatório Diretrizes de 2002, lançado também em português, incorpora novas modificações oriundas da avaliação das partes interessadas. As diretrizes são utilizadas de maneira voluntária por organizações que desejam elaborar relatórios sobre as dimensões econômica, ambiental e social de suas atividades, produtos e serviços. 
lizados no balanço social referente ao ano de 2003 são uma composição dos indicadores de 2002 (GRI adaptado) com os novos, traçados em parceria com o Ethos.

Ao definir o que significa a RSE, a diretora da comissão posiciona-se na defesa do novo profissional que se forma juntamente com a institucionalização da prática social, salientando seu papel e o da recém-criada área de RSE. Ademais, evidencia-se que o modelo proposto de balanço social é apresentado como uma solução apropriada, enaltecendo os benefícios auferidos com sua implementação, para a sociedade e para o fortalecimento dos próprios arranjos estruturais em relação à responsabilidade social.

o pensar socialmente responsável, está permeando todas as áreas dos bancos, não é apenas a área de responsabilidade social [...]. Aliás, algumas coisas são complementares, como quando um banco vai participar de certificação de uma ISO, é a área de qualidade que cuida, mas a área de responsabilidade social é chamada. Muitos dos requisitos passam pela área de responsabilidade social. Então, este mergulho em si mesmo, o papel que este profissional tem junto à sociedade, e que evidentemente se amplia, o papel de sua área junto à sociedade, é um dos grandes benefícios de se fazer um balanço social nos moldes que estamos implantando.

O papel da Febraban junto a seus associados, então, reforça seu lugar de ator-chave na institucionalização da RSE e do balanço social, uma vez que, como representante dos bancos, exerce papel de direcionamento e disseminação das práticas e dos discursos em relação à RSE.

\section{Balanços Sociais dos Bancos/Febraban}

A análise dos balanços sociais preparados pela Febraban, relativos aos anos de 1993 a 2003, revela, por um lado, a evolução da RSE, uma vez que, conforme a questão vai tendo sua abrangência ampliada, isso é espelhado nos balanços sociais. Por outro lado, a análise revela a dinâmica da institucionalização do próprio arranjo estrutural, ao longo dos anos, concomitantemente à institucionalização da RSE, na medida em que o balanço social passa a ser um relatório demandado pela sociedade.

Nas palavras de um superintendente técnico da Febraban, falando sobre a origem e mudança do Balanço Social dos Bancos/Febraban:

[...] os bancos sentiam essa necessidade, porque a comunicação [...] isso tudo foi levando à apreciação interna de que haveria necessidade de mostrar os investimentos feitos pelos bancos em relação à parte social, porque muito se fala de que o banco ganha muito, de que paga pouco imposto, então, o que é que o banco tinha que mostrar efetivamente? O banco [...] é a atividade que secularmente, milenarmente, é condenada, porque pegar dinheiro e emprestar a juros para outro, tem gente que não gosta, mas é um negócio tanto quanto outro. Mas tínhamos que mostrar que [...] o banco paga imposto, o banco investe em obras sociais e tudo mais, propicia emprego, o giro de recursos que propicia os recursos necessários à produção, e tudo isso foi levando os bancos a publicarem [...] então, os bancos individualmente iniciaram, em seguida veio a Febraban e falou, bom, nós temos que fazer alguma coisa também, já fazia em relação ao relatório de atividades, também partiu para o balanço social, e mostra o sistema financeiro como um todo contribuindo para a evolução, para a produção dentro da sociedade. Esse foi o espírito que levou a essas publicações [...].

Explica o superintendente, então, que essa foi a motivação para a publicação do Balanço Social dos Bancos/Febraban. Em seguida, explica a própria evolução do balanço social, ratificando a visão de que ao longo dos anos esse instrumento vai sendo adaptado à realidade do movimento pela RSE:

Depois disso, [relatório de atividades] verificamos a necessidade de apresentar alguma coisa a mais [...]. A partir de 94, passou a se emitir o balanço social, divulgando aspectos de investimento social, [pois o] relatório de atividades era muito técnico sobre o sistema financeiro. Depois, o balanço social começou a 
dar um cunho mais dos investimentos feitos pelo sistema com relação à sociedade. Somente neste ano [2004], o balanço social de 2002 incorpora o espírito de responsabilidade social [...] porque foi criada a condição. Pela primeira vez o balanço social foi elaborado sob o enfoque da responsabilidade social, não só de investimento social, muda então.

Nesse sentido, no primeiro Balanço Social dos Bancos/Febraban, referente ao ano de 1993, na apresentação feita pelo então presidente Alcides Lopes Tápias, fica claro o propósito do relatório quando afirma "[...] acreditamos que é tempo de mostrar o outro lado de nossa atividade: a preocupação com as questões sociais e os benefícios gerados pelos bancos a toda a sociedade [...]" (FEBRABAN, 1994, p.1). Ao final do relatório, esse compromisso social é reforçado, pela justificativa de que é possibilitado pelo bom desempenho do sistema bancário.

Compromisso social: o desempenho rentável da atividade bancária permite aos bancos reafirmar o seu compromisso social, junto às comunidades em que atuam, de contribuir para o desenvolvimento econômico e para a melhoria da qualidade de vida de todos aqueles que, direta ou indiretamente, participam dos destinos do sistema bancário (FEBRABAN, 1994, p.17).

Deve ser ressaltado que, até esse momento, não foi utilizado o termo responsabilidade social, mas sim compromisso social.

A análise dos itens e subitens do Balanço Social dos Bancos de 1993 revela os aspectos que à época foram considerados importantes para se divulgar em um relatório desta natureza, conforme quadro 1 :

\section{Quadro 1 \\ Balanço Social dos Bancos \\ Febraban 1993}

\section{ITENS E SUBITENS}

Bancos como agentes financiadores das atividades

\section{Função social dos bancos}

Força de trabalho

Atuação voltada para a comunidade

Bancos parceiros da sociedade produtivas, como contribuintes muito importantes e como agentes arrecadadores para o governo e empresas públicas.

Perfil da força de trabalho - por idade, sexo, tempo de serviço e escolaridade -, remuneração da força de trabalho, valorização do homem - orçamento social, alimentação, assistência à saúde, treinamento e desenvolvimento, transporte, previdência complementar, segurança no trabalho, atividades complementares e de lazer.

Rede de agências e postos de serviços - exemplos de ações sociais dos bancos - em diversas áreas, atividades culturais e atividades esportivas.

Nesse item, é apresentada uma consolidação de informações denominada Balanço Social, onde consta o número de bancos, de agências, de contas, de funcionários; os valores de impostos, de salários, de benefícios, de gastos com atividades comunitárias; o patrimônio líquido e os dividendos devidos aos acionistas.

Fonte: elaborado com base em Febraban (1994). 
O Balanço Social dos Bancos de 1994 tem também declarada em sua introdução, no texto do então presidente Maurício Schulman, seu propósito:

[...] o trabalho evidencia aspectos pouco divulgados da atividade dos bancos, pertinentes à sua preocupação com as questões sociais e aos benefícios gerados para toda a sociedade, assim como à distribuição do valor adicionado pelo setor (FEBRABAN, 1995, p.1).

Uma novidade no Balanço Social de 1994 foi, então, o "Demonstrativo de valor adicionado (DVA) do setor bancário", que mostra onde foram alocados os recursos gerados pelo sistema bancário (governo, funcionários, acionistas). A introdução desse item é justificada com a afirmação de que muitas empresas européias e americanas, inclusive bancos brasileiros, já o fazem. É, portanto, resultado de um movimento mimético, que busca dar maior respaldo ao balanço social quando, por exemplo, se refere a empresas de outros países, legitimando-o perante a sociedade.

O termo responsabilidade social aparece pela primeira vez, na descrição da função social dos bancos:

[...] com uma política orientada para a obtenção de resultados através da sua atividade primária e da intensiva prestação de serviços, e comprometido com sua responsabilidade social, o sistema bancário desempenha sua missão de agente promotor do desenvolvimento econômico (FEBRABAN, 1995, p.3).

Mais adiante, o termo responsabilidade social aparece, novamente, relacionado ao item sobre a atuação comunitária dos bancos, que descreve as ações sociais, culturais e esportivas: "Atentos à sua responsabilidade social, os bancos são parceiros no desenvolvimento de atividades em benefício das comunidades" (FEBRABAN, 1994, p.18). Nesse item é destacado um dos projetos desenvolvidos a partir daquele ano pela própria Febraban, o Banco de Talentos, que se perpetua até hoje. Isso indica que, embora seja uma associação de representação, ela também atua executando projetos de natureza socialmente responsável, ou seja, ela mesma se insere no movimento pela RSE, não só como representante, mas como organização atuante.

Deve ser lembrado que em 1994 foi implantado o Plano Real, que levou à estabilização da moeda e ao controle da inflação, o que teve forte impacto em todo o setor financeiro, especialmente nas organizações bancárias, implicando ajustamentos no número de funcionários e no tipo de serviço oferecido, entre outros aspectos. Nesse sentido, mais uma peculiaridade do Balanço Social dos Bancos de 1994 é a ênfase nos esforços dos bancos para a adequação de suas estruturas à nova realidade surgida com o Plano Real, o que poderia servir de justificativa para o processo de demissões e terceirização nessas organizações. São destacados também os gastos, principalmente com ações de orientação ao público, decorrentes do Plano Real.

Outra novidade do Balanço Social dos Bancos de 1994, em relação ao de 1993, é a estrutura hierárquica apresentada por sexo, o que evidencia uma disposição do setor em mostrar a questão da discriminação das mulheres no trabalho. São ressaltados também os investimentos em tecnologia, que passam a ser mais volumosos, condizente com as novas estratégias dos bancos. Verifica-se que os termos "compromisso social" e "responsabilidade social" são utilizados quase como sinônimos, ambos vinculados ao desenvolvimento do país.

O Balanço Social dos Bancos de 1995, sem introdução ou apresentação, começa diretamente com o DVA da atividade bancária, enquanto nos anos anteriores começava com o item "A função social dos bancos". O item "Capital humano" trata dos empregos indiretos gerados além do quadro funcional, sem mencionar números, buscando sinalizar que, embora tenham havido demissões, as pessoas estavam sendo alocadas de outras maneiras. Justificando as demissões, é afirmado que "os bancos têm promovido uma contínua adequação nos diversos níveis hierárquicos de suas estruturas, ajustando-as a um cenário de inflação sob controle" (FEBRABAN, 1996, p.6), ou seja, a estabilidade econômica é apresentada como causa da transformação do perfil do bancário. Apresenta somente os percentuais das categorias de funcionários, e não os números absolutos, como nos anos anteriores. 
No item "Bancos parceiros das comunidades" não são apresentados exemplos de ações sociais realizadas, como nos anos anteriores. Verifica-se, então, que no Balanço Social dos Bancos de 1995 pouca ênfase foi dada às ações comunitárias, bem como a outros itens, tendo sido um relatório sucinto. Uma explicação pode ser buscada no momento pelo qual a economia e as organizações bancárias estavam passando, em função do Plano Real, mas não podemos isso afirmar. A partir desse ano não aparece mais no resumo final a linha "lucro líquido", como em 1993 e 1994. Uma inclusão no "Balanço social" (resumo) é a linha sobre a participação nos lucros e resultados, que decorre de acordo coletivo com a categoria.

O Balanço Social de 1996, também sem introdução ou apresentação, mostra dados comparativos aos dois anos anteriores em relação ao primeiro item, "O banco é a sua equipe de funcionários". Nele fica evidenciado o ajuste na estrutura, com destaque para a redução no número de chefias e para a terceirização das atividades não essencialmente bancárias. Essa ênfase em torno da questão funcional decorre, como já mencionado, das demissões que estavam acontecendo no setor, buscando enfatizar o treinamento e os benefícios auferidos pelos funcionários que se mantiveram nos bancos. O item seguinte trata da "Função dos bancos: prestar serviços financeiros", detalhando suas atividades, expansão etc, destacando-se os novos tipos de atendimentos existentes: pelo telefone, por computador etc.

O item "A responsabilidade social dos bancos" trata das ações sociais, culturais e esportivas dos bancos. Evidencia-se, então, que o termo responsabilidade social é utilizado para designar especificamente os projetos das organizações voltados para as comunidades, não sendo utilizado de forma mais ampla. O Balanço Social dos Bancos de 1996 é finalizado com o item sobre o "Valor adicionado pela atividade bancária" e com o resumo "Balanço social".

Em relação ao Balanço Social dos Bancos de 1997, o relatório volta a ter uma mensagem do presidente da Febraban, que afirma que as "grandes mudanças ocorridas no sistema bancário em conseqüência da estabilidade da moeda e da abertura econômica provocaram alterações substanciais no setor" (FEBRABAN, 1998, p.1). É ressaltado, então, que o contingente de empregados diminuiu em função das reformulações administrativas, da terceirização das atividades-meio, da automação e da busca de produtividade, o que acarretou a mudança do perfil do bancário - que passa a ter maior nível de escolaridade. Afirma também, por outro lado, que se ampliaram de forma expressiva os investimentos em projetos sociais e que merece destaque a construção de teatros e centros culturais. Assim, finalizando sua apresentação, o então presidente Roberto Egydio Setúbal afirma:

Assumindo postura mais participativa, os bancos se credenciam como parceiros daqueles que querem um futuro melhor e mais justo para todos os brasileiros, investindo recursos próprios no bem-estar da comunidade (FEBRABAN, 1998, p.1).

Nessa mensagem fica aparente que o investimento em projetos sociais busca melhorar a imagem das organizações bancárias, em decorrência da onda de demissões que se verificava naquele momento, funcionando, então, como uma ação que justifica e compensa a atuação dos bancos. Contudo, contraditoriamente, coincidentemente ou não, a partir desse relatório, no item final, de resumo das informações, não consta mais o valor gasto em atividades comunitárias, como até o momento acontecia.

No item "Bancos, parceiros atuantes da comunidade", novamente, é utilizado o termo responsabilidade social para designar os investimentos em projetos comunitários:

O sistema financeiro [...] [entende como] uma forma de retornar à sociedade parte dos resultados obtidos com sua atuação empresarial [...] O que reflete a atenção que o sistema financeiro vem dando à sua responsabilidade social (FEBRABAN, 1998, p.8).

Por outro lado, em subitem sobre o comprometimento com as questões comunitárias afirma-se que: "estas atividades estão fundamentadas no conceito de cidadania empresarial: o comprometimento da iniciativa privada com as questões comunitárias" (FEBRABAN, 1998, p.8). Começa então a aparecer repetidamente os termos 
responsabilidade social e cidadania empresarial, que também são utilizados quase como sinônimos, sempre voltados à relação com a comunidade.

O Balanço Social dos Bancos de 1998 começa dizendo a que veio o balanço social - um instrumento de gestão e de informação pelo qual a empresa demonstra o cumprimento de sua função social. Afirma ainda o presidente da Febraban que,

Tem-se notado, de alguns anos para cá, uma crescente consciência de que a empresa pode e deve assumir, dentro da sociedade, um papel mais amplo, transcendente ao de sua vocação básica de geração de riquezas. O papel da iniciativa privada na construção do Brasil do próximo milênio é um novo e grande desafio para a comunidade empresarial. Trata-se de uma inovadora relação com a sociedade e com o mundo dos negócios, que possibilita o enfrentamento das adversidades sociais. Consiste no investimento de recursos tecnológicos, financeiros e humanos na formação da chamada cidadania empresarial [...] A empresa privada é co-responsável, com a administração pública, pelos problemas que atingem a comunidade. Empresas-cidadãs e socialmente responsáveis, os bancos vêm contribuindo para a melhoria da qualidade de vida e para a construção de uma sociedade mais justa (FEBRABAN, 1999, p.1).

O Balanço Social de 1998 traz, então, a novidade de se teorizar sobre o assunto, sobre a função do balanço social e sobre o papel da empresa na sociedade, reforçando e divulgando o discurso das parcerias e da coresponsabilização. Deve ser lembrado que em 1997 foi lançada a Campanha pelo Balanço Social do Ibase, momento crítico para o movimento pela RSE, pois promoveu a discussão e ajudou a levar ao conhecimento popular esse instrumento que busca retratar a atuação social da empresa.

No item sobre a força de trabalho aparece pela primeira vez o cálculo do turnover dos bancos, por categorias, por escolaridade, por idade, por tempo de casa e por local de trabalho. No item sobre o cliente é dado destaque para os investimentos/custos para a segurança no bug do ano 2000. Também é dada ênfase no crescimento do número de transações com cartões, reflexo do investimento feito em tecnologia pelos bancos.

Na mesma linha de teorização sobre a RSE, constante na apresentação do Balanço Social dos Bancos de 1998, no item que trata das relações comunitárias, há um texto de duas páginas sobre o papel do Terceiro Setor e das parcerias com empresas, o que indica a interação que se objetiva conseguir com a sociedade civil, por meio do Terceiro Setor. É, portanto, uma forma de justificar a escolha do tipo de atuação e de valorizar e disseminar esse caminho. Logo após o texto são apresentadas as ações sociais, culturais e esportivas realizadas pelos bancos, como nos anos anteriores.

Diferentemente dos balanços sociais dos outros anos, a partir do Balanço Social dos Bancos de 1998 não é apresentado o "balanço social/informações gerais", embora a maioria dos dados possa ser buscada internamente nesse relatório. Aparecem também, muitas vezes, os termos "responsabilidade social" e "empresa-cidadã".

No Balanço Social dos Bancos de 1999 percebe-se maior qualidade do encarte/apresentação, o que implica maior investimento em sua preparação, o que pode ser entendido como reflexo da campanha pelo balanço social. Consoante a isso, inicia com um índice na primeira página, dando caráter mais organizado à publicação. Logo adiante, antes da mensagem do presidente, são apresentados quatro textos definindo a RSE, de autoria de empresários e acadêmicos renomados. ${ }^{10}$ Sendo os autores pessoas públicas, de diferentes meios, esses textos sobre RSE têm o papel de dar credibilidade ao documento e legitimar, ao mesmo tempo, o movimento que lhe

\footnotetext{
${ }^{10}$ Olavo Egydio Setúbal - diretor presidente da Itaúsa, prefeito de São Paulo (1975-79) e ministro das Relações Exteriores; José Mindlin fundador da Metal Leve, patrono da cultura e secretário da Cultura, Ciência e Tecnologia do Estado de São Paulo (1975-76); Antonio Carlos Ronca Caruso - reitor da Pontifícia Universidade Católica de São Paulo; e Evelyn lochepe - presidente fundadora do Grupo de Institutos Fundações e Empresas (Gife), diretora presidente da Fundação lochpe.
} 
dá origem - desta vez, assumindo o termo responsabilidade social para designar o processo, como se verifica em um dos textos, citado adiante para exemplificação:

Responsabilidade social sempre foi um compromisso das empresas saudáveis, apesar da novidade do rótulo. Empresas modernas e competitivas exercem essa função de maneira focada e estratégica, para efetivamente fazerem diferença em seu ambiente. E têm colhido dividendos na comunidade, que as percebe como parceiras, e entre funcionários, que se sentem valorizados por pertencerem a organizações que partilham de seus anseios mais particulares e, portanto, universais - Evelyn Berg Iochepe (FEBRABAN, 2000, p.2).

O argumento utilizado pela autora relaciona claramente a RSE com a modernidade da empresa, ressaltando os benefícios dessa atuação estratégica no social.

Mais adiante, na apresentação do presidente é reforçada a utilização do termo responsabilidade social, a atuação da empresa-cidadã e o papel do balanço social:

[...] Atentos à sua responsabilidade social, os bancos, paralelamente à remuneração direta da força de trabalho e programas internos de benefícios, investem recursos próprios muito significativos em projetos sociais dirigidos a comunidades carentes e de apoio [...] O Balanço Social dos Bancos [...] evidencia essa ação dos bancos, seu comprometimento com o corpo de funcionários e os serviços que, com o emprego da tecnologia de ponta, prestam à sociedade. (FEBRABAN, 2000, p.2)

Verifica-se, então, que apesar do novo discurso de justificação, mais amplo - e que busca maior legitimidade dentro do movimento que já está crescente na sociedade -, os alvos da RSE continuam os mesmos: os funcionários e as comunidades. Ainda não se discursa sobre a transformação dos procedimentos de trabalho e da cultura da organização. São, portanto, ações que não alteram a forma de conduzir os negócios, mantendo-se os mesmos processos, produtos e negócios.

Na mesma linha de teorização sobre o assunto, a introdução do Balanço Social dos Bancos de 2000 traz uma frase do sociólogo Herbert de Souza: "Realizar o Balanço Social significa uma grande contribuição para a consolidação de uma sociedade verdadeiramente democrática" (FEBRABAN, 2001, p. 1), o que serve de reforço na importância dessa divulgação. O discurso do novo presidente, Gabriel Jorge Ferreira, ratifica e estende o tom dos balanços anteriores:

Além do lado ético e humano que a responsabilidade social envolve, as ações realizadas pelas empresas em benefício das comunidades onde atuam tornaram-se, nos anos mais recentes, uma questão de estratégia e de sobrevivência a longo prazo. (FEBRABAN, 2001, p.1)

No item sobre a atuação comunitária, as mudanças nos termos são muitas. As ações sociais passam a ser chamadas de investimento social e a serem ligadas ao conceito de desenvolvimento sustentável, o que já é um reflexo da adequação do movimento a termos utilizados em todo o mundo. Contudo, os casos apresentados são da mesma natureza dos anos anteriores. Nesse sentido, muitos projetos e programas aparecem repetidas vezes ao longo dos anos, principalmente aqueles realizados pelos grandes bancos e por suas fundações, como é o caso da Fundação Bradesco, Fundação Banco do Brasil, Instituto Unibanco, Itaú Social, Fundação BankBoston e o Real ABN, por exemplo; talvez, por serem os mais relevantes.

O Balanço Social de 2001 ganhou o título "Os bancos e a sociedade", o que evidencia seu propósito de ser um elo entre o setor e a sociedade. A frase citada junto ao índice remete ao discurso em formação sobre a solidariedade entre os povos, e onde a RSE estaria inserida: "Os problemas do mundo só serão resolvidos com solidariedade." (FEBRABAN, 2002, p.1).

A apresentação do presidente ganhou título também: “A importância da ação social”. É, então, enfatizada sua importância, além de tratar de outros assuntos, como o volume de serviços prestados, investimentos realizados 
para melhorar o atendimento bancário e a relevância das informações sobre os bancários. No item "Atendimento e serviços" é feita uma comparação de três anos, inovando com a apresentação do subitem Operações de Crédito do Sistema Financeiro por tipo de setor produtivo. Mesmo sendo o primeiro ano desse subitem, os dados são comparados com dois anos anteriores, como os demais itens. Verifica-se, então, que o balanço social vai refinando a forma e a amplitude das informações, no sentido de possibilitar comparações com outros períodos e de ir ampliando seu escopo.

No item relacionado aos "Recursos humanos", o destaque é para a participação das mulheres. O item turnover aparece somente por categorias, diferentemente dos anos anteriores. Não é publicada a parte de apuração e retenções do DVA - somente a distribuição dos valores. No tópico sobre as ações comunitárias, a novidade é um item específico para o "voluntariado" e um para o "meio ambiente". Esse item revela, então, a adequação do balanço social às demandas sociais, lembrando, por exemplo, que 2001 foi proclamado pela Organizações das Nações Unidas (ONU) o Ano Internacional do Voluntariado. No subitem "Meio Ambiente - cuidado essencial", são apresentados projetos antigos de alguns bancos, mas ressaltando-se o fundamento das ações em meio ambiente como parte do desenvolvimento sustentável. Duas páginas são destinadas exclusivamente aos projetos sociais dos bancos ligados ao Programa Comunidade Solidária, do governo federal (em outros anos já aparecia, mas não com tanto destaque). Outra inovação foi a apresentação, ao final, de uma lista de ONGs apoiadas pelos bancos.

O Balanço Social dos Bancos de 2002, agora impresso em papel reciclado, inova e ganha novo título: Os bancos, seus públicos e a sociedade. O balanço foi reestruturado, buscando tratar a performance das instituições em três linhas finais de resultados: a econômica, a social e a ambiental, de acordo com as orientações do GRI, trazendo maior legitimidade para o relatório. Dessa forma, a partir dessa publicação fica firmado o discurso da RSE, do qual passa a fazer parte também o negócio da empresa. É, portanto, um momento crítico para o movimento pela RSE no setor bancário, onde os discursos organizacionais passam a ser realinhados de modo a espelhar essa forma de atuação socialmente responsável.

Na apresentação do Balanço Social de 2002, o presidente enfatiza a necessidade de que as ações junto às comunidades estejam cada vez mais alinhadas a uma agenda nacional de desenvolvimento:

[...] estamos dando um novo passo que irá, gradualmente, promover uma mudança de patamar em nosso reporte de resultados diante da sociedade e dos diferentes públicos dos bancos: a incorporação da perspectiva de sustentabilidade e responsabilidade empresarial [...] a Febraban [...] se dispõe a influenciar os bancos para que cada vez mais aprofundem seus compromissos com o país nos planos econômico, social e ambiental [...] espelha-se nas várias iniciativas que visam sistematizar, organizar e formalizar o papel do segmento financeiro em conceitos e práticas de sustentabilidade e responsabilidade corporativa [...] Todos esses são sinais inequívocos da influência crescente da sociedade sobre a atividade empresarial e desdobramentos dos "Princípios do Equador" ", que definem diretrizes do envolvimento do setor financeiro com questões ligadas ao desenvolvimento sustentável e à difusão do pensamento ligado a sustentabilidade de modo geral (FEBRABAN, 2004a, p.3).

Evidencia-se, então, uma mudança na atitude da federação, se comparada com o resultado da pesquisa efetuada por Cappellin et al (2002). Além disso, outro aspecto a ser destacado é a mudança radical que acontece nesse relatório em relação aos termos utilizados para se referir ao movimento: sustentabilidade e responsabilidade corporativa parecem ocupar o lugar do termo compromisso social e, também, em menor medida, do termo responsabilidade social.

\footnotetext{
${ }^{11}$ Os chamados "Princípios do Equador" são um conjunto de regras baseadas em critérios desenvolvidos pela International Finance Corporation (IFC), braço financeiro do Banco Mundial, para concessão de crédito, tendo em vista critérios mínimos ambientais e de responsabilidade social.
} 
O relatório de 2002 também é mais abrangente em outros aspectos. É apresentado o perfil da federação, sua visão, missão, valores, além de sua estrutura e funcionamento, evidenciando que a própria Febraban passou por um processo interno de repensar seu papel. É ressaltada a criação de comissão específica para responsabilidade social, ao lado das demais vinte comissões técnicas. Por meio dessa comissão, então, com pessoas dedicadas exclusivamente ao tema da RSE, é impresso um novo formato e conteúdo ao Balanço Social.

O relatório ainda contextualiza o cenário brasileiro, citando o elevado "Risco Brasil" do período, mostra a importância da Febraban e dos bancos no projeto do Sistema de Pagamentos Brasileiros e destaca as novas opções de atendimento bancário.

No novo item "Negócios, sustentabilidade e responsabilidade corporativa", é reafirmado que as organizações bancárias conhecem o papel que desempenham na sociedade:

O desempenho de suas funções coloca os bancos em uma posição de grande influência no cotidiano de empresas, governos, comunidades e, em última análise, na vida das pessoas. Por isso a atuação do segmento financeiro da economia se torna cada vez mais importante para o desenvolvimento sustentável e para o incentivo à responsabilidade empresarial. (FEBRABAN, 2004a, p.16)

Os indicadores de desempenho desse item referem-se a 57 bancos associados que responderam à pesquisa, e abordam os seguintes tipos de público/ações:

- clientes (incluindo crédito imobiliário e microcrédito - acompanhamento do impacto das operações);

- colaboradores (incluindo dados por sexo, e diversidade - cor/raça);

- fornecedores;

- meio ambiente (apresentando critérios socioambientais na concessão de crédito, além de iniciativas de coleta seletiva, reciclagem etc.); e

- ações sociais e comunitárias (apresentando os incentivos fiscais utilizados pelos bancos).

Como se pode constatar pelos indicadores anteriormente citados, o Balanço Social dos Bancos de 2002 inova com uma abordagem voltada para o negócio e uma preocupação com diferentes aspectos da gestão da organização. Deve ser salientado o trabalho demandado para elaboração desse balanço social, conduzido pela Comissão de Responsabilidade Social da Febraban. Até a data da entrevista na Febraban, em janeiro de 2004, o Balanço Social de 2002 ainda não tinha sido divulgado. Além da elaboração dos indicadores e do questionário, que demandou maior esforço da Febraban do que nos anos anteriores, os bancos também tiveram dificuldades nas respostas, por não estarem devidamente preparados para responder a muitos dos itens solicitados, o que pôde ser evidenciado em algumas entrevistas realizadas em bancos. ${ }^{12} \mathrm{O}$ próprio questionário para o Balanço Social dos Bancos - mesmo que não respondido ou que parcialmente respondido - sinaliza e direciona o movimento pela RSE nas organizações bancárias, pois, a partir dele elas podem redirecionar suas ações e ampliar seu entendimento sobre a RSE, concernentes às características definidas pela Febraban.

O Balanço Social dos Bancos de 2003, também impresso em papel reciclado, integrou os indicadores utilizados no Balanço Social de 2002 (baseados no GRI) aos indicadores desenvolvidos em parceria com o Instituto Ethos, específicos para o setor financeiro. Como a adesão à pesquisa é voluntária, é esclarecido que a base de dados para análise é constituída a partir das informações dos bancos participantes, relacionando o percentual de participação ao ativo total do sistema bancário, como forma de dar a dimensão da amostra. Todavia, embora tenhamos obtido a informação junto a representantes da Febraban sobre o número de respondentes (41 bancos), essa informação não aparece no Balanço Social dos Bancos de 2003. Deve ser lembrado que nem sempre os

\footnotetext{
${ }^{12}$ Essas outras entrevistas realizadas em bancos fazem parte de pesquisa de doutorado realizada pela autora, que investiga a dinâmica de institucionalização do movimento pela RSE no campo das organizações bancárias.
} 
bancos respondem a todos os itens do questionário, e que somente em algumas questões específicas foi mencionado o número de bancos que responderam. Nas demais, não é possível visualizar a que universo se referem os percentuais apresentados.

Deve ser ressaltado também que esse relatório referente ao ano de 2003 ficou pronto somente no mês de dezembro de 2004, evidenciando, por um lado, a dificuldade e a demora dos bancos em responder ao questionário e, por outro, a dificuldade em se trabalhar os dados enviados pelos bancos, conforme entrevistas realizadas.

No Balanço Social de 2003, o termo responsabilidade social continua perdendo espaço para sustentabilidade e responsabilidade corporativa, como fica evidenciado na mensagem da diretoria:

[...] representa mais um passo [...] no esforço de incentivar a integração de princípios de sustentabilidade e responsabilidade empresarial às práticas negociais do setor bancário [...] no sentido de estimular o permanente engajamento das instituições financeiras em três linhas mestras de ação [...](FEBRABAN, 2004b, p.3).

No item "Negócios, sustentabilidade e responsabilidade corporativa", é reforçado esse argumento:

[...] De todos, talvez seja o setor financeiro aquele que mais tem avançado no sentido de considerar a perspectiva da sustentabilidade e responsabilidade corporativa em suas práticas e nas práticas de seus diferentes públicos, de acionistas e clientes [...] mas, ainda há muito a fazer, uma vez que sustentabilidade e responsabilidade empresarial possuem uma natureza sistêmica. Os resultados [...] mostram um movimento de como o setor financeiro continua exercendo sua influência (FEBRABAN, 2004b, p.19).

É destacado o papel que a RSE tem na gestão do negócio e o papel que o sistema financeiro desempenha em outros setores, uma vez que tem avançado segundo essa perspectiva da sustentabilidade. Ainda nesse item, é destacado o fato de que as instituições financeiras estejam se envolvendo com os cuidados para a concessão de crédito, passando pela adoção de critérios diferenciados na formação de carteiras para investimentos socialmente responsáveis.

Em relação aos produtos bancários - que agora passam a fazer parte também da discussão sobre a responsabilidade social dos bancos -, dentro dessa perspectiva mais ampla de sustentabilidade e responsabilidade corporativa, justificam a inclusão, por exemplo, das ações relacionadas ao microcrédito:

Trata-se de uma iniciativa reconhecida e recomendada por organismos internacionais, que pode facilmente vincular-se a uma agenda nacional de desenvolvimento e se constituir em um mecanismo para promover a inclusão social, gerar e distribuir renda (FEBRABAN, 2004b, p.19).

O discurso que justifica a inclusão desse produto na agenda empresarial, então, passa pela demanda dos organismos internacionais, como a ONU, e pelo discurso das parcerias com o poder público na luta contra a exclusão social.

$\mathrm{Na}$ apresentação do item "Relação com os diferentes públicos", 13 essa preocupação é justificada de acordo com o discurso prevalecente no meio social atualmente:

\footnotetext{
${ }^{13}$ O item "Relação com os diferentes públicos" apresenta os seguintes subitens: 'Meio Ambiente" - incluindo integração de aspectos socioambientais no negócio (como análise de crédito) e ecoeficiência (uso de recursos) -, "Colaboradores", "Fornecedores", "Consumidores e clientes", "Governo e sociedade" e "Relações com a comunidade" - que além de ação social e voluntariado, inova com o "Comunidade e negócio", que inclui o microcrédito.
} 
[...] a consciência de que sustentabilidade e responsabilidade possuem uma dimensão sistêmica e, portanto, exigem a formação de redes de relações entre os diferentes sujeitos sociais - empresas, organizações da sociedade civil, cidadãos e governo - tem oferecido às empresas uma nova noção da complexidade da gestão de seus negócios e desenvolvido novos contextos de competitividade. (FEBRABAN, 2004b, p.21)

Entre outros pontos, esclarece o texto que, dos bancos que participam do relatório:

- $80 \%$ dispõem de uma política capaz de orientar o diálogo com seus públicos, embora apenas tenham começado a aperfeiçoá-la;

- 95\% dos bancos possuem declaração de crenças e valores e/ou código de conduta documentados, buscando pautar suas relações por essas premissas;

- mais de $90 \%$ adotam procedimentos formais para o tratamento de questões em relação a condutas que envolvam ações como lavagem de dinheiro, identificação de recursos provenientes de tráfico de drogas, armas e terrorismo, entre outras;

- $42,5 \%$ publicam anualmente relatório de responsabilidade corporativa e aproximadamente $70 \%$ disponibilizam esses dados também pela Internet.

Reafirmamos, todavia, a falta de uma referência para compreensão sobre o que realmente esses números revelam, uma vez que não aparece no relatório o número de bancos respondentes, além do fato de que há sempre um certo viés por parte daqueles que respondem - ou eles responderam porque têm as informações mais organizadas, ou porque já tem os processos mais adiantados - e dos que não respondem. De qualquer forma, tendo conhecimento de que dentre os 41 bancos que responderam à pesquisa estão os mais importantes em termos de volumes de transações, clientes etc., os dados são um indicativo da inserção das organizações bancárias no movimento pela RSE. ${ }^{14}$

No quadro 2 pretendemos, ao resumir os itens utilizados nos balanços sociais em cada ano, evidenciar a evolução da RSE e do próprio arranjo estrutural. No quadro aparecem também as quantidades de páginas de cada relatório, evidenciando que, de um relatório pequeno, em 1993, torna-se um amplo relatório, com 64 páginas em 2003, o que, no mínimo, revela maior quantidade de informações e de investimento em sua preparação.

\footnotetext{
${ }^{14}$ Durante a pesquisa de campo para a tese de doutorado, encontramos bancos que declararam não ter respondido ao questionário da Febraban para elaboração do balanço social por considerá-lo exageradamente detalhista, e o banco não ter todas aquelas informações, da forma solicitada, ou porque o conjunto das questões é mais voltado a bancos de varejo, fugindo, por exemplo, da realidade de um banco de investimento, em muitos itens.
} 
Quadro 2

Itens dos balanços sociais dos bancos

Febraban (1993-2003)

\begin{tabular}{|c|c|c|}
\hline ANO & Nơ DE PÁGINAS & ITENS \\
\hline 1993 & 17 & $\begin{array}{l}\text { Pequena apresentação; A função social dos bancos; A força de } \\
\text { trabalho; Valorização do homem; A atuação voltada para a } \\
\text { comunidade; Bancos parceiros da sociedade (incluindo o resumo } \\
\text { "Balanço social"). }\end{array}$ \\
\hline 1994 & 32 & $\begin{array}{l}\text { Pequena apresentação; A função social dos bancos; Uma força de } \\
\text { trabalho polivalente; Atendimento aos clientes; Atuação comunitária; } \\
\text { Valor adicionado e Balanço social. }\end{array}$ \\
\hline 1995 & 11 & $\begin{array}{l}\text { O valor adicionado pela atividade bancária; Os bancos a serviço da } \\
\text { economia; Investimentos em informática e telecomunicações; O } \\
\text { capital humano; Bancos parceiros das comunidades e Balanço social. }\end{array}$ \\
\hline 1996 & 24 & $\begin{array}{l}\text { O banco é a sua equipe de funcionários; A remuneração da força de } \\
\text { trabalho; Valorização da equipe de funcionários; O investimento na } \\
\text { formação da equipe; Função dos bancos; prestar serviços financeiros; } \\
\text { A responsabilidade social dos bancos; O valor adicionado pela } \\
\text { atividade bancária e Balanço social. }\end{array}$ \\
\hline 1997 & 14 & $\begin{array}{l}\text { Apresentação do presidente; A força de trabalho que impulsiona os } \\
\text { bancos; Tecnologia de ponta à disposição da clientela; Bancos, } \\
\text { parceiros atuantes da comunidade; Apoio à atividade econômica e } \\
\text { Informações gerais (substitui o resumo "Balanço social"). }\end{array}$ \\
\hline 1998 & 32 & $\begin{array}{l}\text { Apresentação do presidente; O principal ativo dos bancos: sua força } \\
\text { de trabalho; Qualidade total - foco no cliente; Melhoria da qualidade } \\
\text { de vida: o terceiro setor amplia seu espaço e Valor Adicionado. }\end{array}$ \\
\hline 1999 & 36 & $\begin{array}{l}\text { Conteúdo; Citações; Apresentação do presidente; A força que } \\
\text { impulsiona os bancos; Atendendo à coletividade; Bancos: assumindo } \\
\text { seu papel de empresas-cidadãs; Demonstrativo do valor adicionado } \\
\text { (DVA) e A democratização do capital.. }\end{array}$ \\
\hline 2000 & 32 & $\begin{array}{l}\text { Apresentação do presidente; Recursos humanos: o principal ativo dos } \\
\text { bancos; Atendendo à coletividade: A distribuição da riqueza gerada } \\
\text { pelos bancos; O investimento social dos bancos na busca do } \\
\text { desenvolvimento sustentável. OBS;: a partir desse ano, não aparece } \\
\text { mais o resumo "Balanço social". }\end{array}$ \\
\hline 2001 & 31 & $\begin{array}{l}\text { Conteúdo; Apresentação do presidente; Atendimento e serviços; } \\
\text { Investimentos; Recursos humanos e Ações sociais e comunitárias. }\end{array}$ \\
\hline 2002 & 48 & $\begin{array}{l}\text { Conteúdo; Apresentação (mensagem da diretoria); A Febraban; O } \\
\text { setor bancário brasileiro em 2002; Negócios, sustentabilidade e } \\
\text { responsabilidade corporativa; Indicadores de desempenho de bancos } \\
\text { associados e Ações sociais e comunitárias. }\end{array}$ \\
\hline 2003 & 64 & $\begin{array}{l}\text { Conteúdo; Apresentação (mensagem da diretoria); A Febraban; O } \\
\text { setor bancário brasileiro em 2003; Orientação ao leitor; Negócios, } \\
\text { sustentabilidade e responsabilidade corporativa; Relação com os } \\
\text { diferentes públicos (meio ambiente, colaboradores, fornecedores, } \\
\text { consumidores e clientes, governo e sociedade) e Relações com a } \\
\text { comunidade. }\end{array}$ \\
\hline
\end{tabular}

Fonte: elaborado com base em Febraban (1994-2004b). 
Observa-se no quadro 2 que alguns itens vão surgindo, outros sumindo ou tendo sua denominação alterada, o que é também um reflexo de transformações organizacionais e sociais. Como exemplo, o tópico que trata dos funcionários: em 1993, era denominado "A força de trabalho"; em 1995, "Capital humano"; em 1998, "O principal ativo dos bancos: sua força de trabalho"; em 2000, "Recursos humanos"; em 2002/3, "Colaboradores". Se essas alterações refletem, por um lado, as transformações da área de recursos humanos, buscando a valorização e o desenvolvimento do homem, por outro, servem de justificativa em relação às demissões no setor durante o período analisado, como será evidenciado na tabela 2. Outras transformações sociais podem ser visualizadas a partir dos itens, como a ênfase no investimento em tecnologia que, por um lado, possibilita o enxugamento e a terceirização dos quadros e, por outro, implica maior investimento na capacitação dos funcionários que permanecem, entre outros aspectos. Também no quadro 2 evidencia-se a mudança de foco das informações do balanço social, que passa a incluir também o "negócio", a partir de 2002.

Consoante a essa análise, da tabela 2 depreende-se uma mudança no perfil do bancário. As categorias de diretores e de técnicos de nível universitário aumentaram numericamente, ao passo que as outras diminuíram abruptamente, com as demissões e terceirização de serviços não-essenciais, refletindo a reestruturação das organizações do setor bancário.

\section{Tabela 2}

Empregados no setor bancário, por categorias

\begin{tabular}{lcccccc}
\hline \multirow{2}{*}{ Ano } & Diretores & \begin{tabular}{c} 
Gerentes e \\
chefes \\
\cline { 2 - 7 }
\end{tabular} & $\begin{array}{c}\text { Caixas e } \\
\text { supervisores }\end{array}$ & $\begin{array}{c}\text { Técnicos de } \\
\text { esível } \\
(1)\end{array}$ & $\begin{array}{c}\text { Outros } \\
\text { funcionários } \\
\text { universitário }\end{array}$ & $\begin{array}{c}\text { Total } \\
(2)\end{array}$ \\
\hline $1993(3)$ & 2.259 & 178.379 & 415.859 & 46.082 & 31.921 & 674.500 \\
\hline 1994 & 2.937 & 167.436 & 400.604 & 47.608 & 24.333 & 642.918 \\
\hline $1995(3)$ & 1.957 & 140.655 & 352.016 & 44.086 & 19.976 & 558.691 \\
\hline 1996 & 2.045 & 124.108 & 322.016 & 34.182 & 14.758 & 497.109 \\
\hline 1998 & 1.863 & 115.026 & 300.949 & 34.296 & 11.196 & 463.330 \\
\hline 1999 & 1.873 & 107.959 & 272.403 & 42.307 & 11.305 & 435.847 \\
\hline 2000 & 1.838 & 116.188 & 239.931 & 47.273 & 9.573 & 414.803 \\
\hline 2001 & 1.754 & 113.703 & 229.390 & 46.572 & 9.435 & 400.854 \\
\hline $2002(4)$ & 2.523 & 103.982 & 226.096 & 63.820 & 6.426 & 402.847 \\
\hline 2003 & 3.794 & 89.800 & 207.022 & 84.258 & 3.593 & 388.467 \\
\hline
\end{tabular}

(1) e auxiliares, recepcionistas, secretárias e operadores;

(2 inclui contínuos, vigias, pessoal de limpeza e manutenção.

(3) baseado no Balanço Social de 1994, com o qual é comparado, já que as categorias sofreram alterações. Os dados de 1993 aparecem posteriormente, em balanços de outros anos, divididos em categorias diferentes da original.

(4) no Balanço Social de 2002, as categorias se alteram, aparecendo "superintendentes", que somamos a "diretores".

(5) dados não disponíveis.

Fonte: elaborado com base em Febraban (1994 a 2004b).

Observa-se mais uma vez que, embora o Balanço Social dos Bancos de 2003 traga muitas novidades e avanços, os dados não estão compatibilizados com os balanços dos anos anteriores, o que prejudica a análise longitudinal.

Na tabela 3, evidencia-se declínio no número de bancos no Brasil, indicando a concentração do sistema bancário, o que decorre, principalmente, de processos de fusões e aquisições, já mencionados. 
Tabela 3

Setor bancário

Número de bancos, agências, postos, contas correntes e contas de poupança

(1993-2003)

\begin{tabular}{|c|c|c|c|c|}
\hline \multirow{2}{*}{ Indicador } & \multirow{2}{*}{ Bancos } & \multirow{2}{*}{$\begin{array}{l}\text { Agências e postos de } \\
\text { atendimento }\end{array}$} & \multicolumn{2}{|c|}{ No de Contas (em Milhões) } \\
\hline & & & Contas correntes & poupança \\
\hline 1993 & 244 & 31.000 & 44,0 & 47,0 \\
\hline 1994 & 246 & 31.922 & 37,4 & 47,0 \\
\hline 1995 & 241 & 32.319 & 40,0 & 53,0 \\
\hline 1996 & 234 & 25.713 & 40,0 & 67,0 \\
\hline 1997 & 217 & 24.671 & 42,4 & 52,1 \\
\hline 1998 & 203 & 24.213 & 45,0 & 40,0 \\
\hline 1999 & 194 & 23.423 & 49,9 & 44,8 \\
\hline 2000 & 193 & 23.848 & 55,8 & 45,8 \\
\hline 2001 & 181 & 24.159 & 63,2 & 51,2 \\
\hline 2002 & 173 & $\begin{array}{c}24.157 \\
*) 13.950\end{array}$ & 66,7 & 58,0 \\
\hline 2003 & 161 & $\begin{array}{c}23.988 \\
*) 15.874\end{array}$ & 71,5 & 62,4 \\
\hline
\end{tabular}

$\left(^{*}\right)$ número de correspondentes bancários.

Fonte: elaborado com base em Febraban (1994 a 2004a).

Por outro lado, apesar dessa diminuição, observa-se na tabela 3 aumento no número de contas correntes e de contas de poupança, evidenciando maior acesso da população ao sistema financeiro - o que pode ser explicado pelas políticas nesse sentido, como a questão dos correspondentes bancários, e pela estabilidade monetária a partir de 1994. Depreende-se da análise, também, que a tecnologia de informação teve papel essencial nas modificações ocorridas no setor bancário.

\section{Considerações finais}

Neste artigo analisamos os balanços sociais dos bancos preparados pela Febraban, num período de 11 anos. A análise mostra que o balanço social vai sendo modificado de modo a espelhar transformações na prática e no discurso da responsabilidade social dos bancos, fornecendo-nos um referencial do processo de institucionalização da RSE. De um relatório relativamente simples, o Balanço Social dos Bancos/Febraban passa a um elevado nível de sofisticação, incorporando as dimensões econômica, ambiental e social de suas atividades, produtos e serviços, o que evidencia a amplitude que o fenômeno vai adquirindo no Brasil. Na medida em que o tema vai ganhando destaque no país, então, o Balanço Social dos Bancos vai sendo refinado e modificado de modo a espelhar os novos padrões exigidos pela sociedade, numa reorientação das ações com vistas à aquisição de legitimidade social.

São percebidos três períodos distintos na publicação do Balanço Social dos Bancos/Febraban. Até 1998, o relatório era quase que exclusivamente voltado para as ações sociais dos bancos. A tônica da publicação era o compromisso social - ações sociais, culturais e esportivas que evidenciassem a cidadania empresarial dos bancos. Desde então até 2001 - período em que o próprio instrumento balanço social ganhou maior relevância junto à sociedade, na medida em que passou a ser mais conhecido e demandado - a ênfase do Balanço Social dos Bancos/Febraban foi, pouco a pouco, sendo modificada - expressa na adoção do termo responsabilidade social. Entretanto, é a partir de 2002, quando a própria Febraban passou por um processo de reorientação de valores - passo desejado e necessário, segundo Motta (1981), para se chegar a um conceito de responsabilidade social que vá ao encontro dos anseios sociais -, que o Balanço Social dos Bancos passa a refletir essa 
transformação, integrando a questão do negócio bancário à discussão da RSE. A partir de 2002, então, tendo à frente do balanço social grupo específico para lidar com a questão na Febraban, foram incorporadas novas dimensões ao balanço social, acompanhando a crescente institucionalização da prática da responsabilidade social no Brasil e no mundo. Além disso, os balanços sociais analisados refletem transformações organizacionais e sociais ao incluir itens e ao mudar a denominação de alguns deles.

Outra conclusão da análise relaciona-se aos termos utilizados ao longo dos anos, levando-nos à reflexão sobre a institucionalização da RSE. Conclui-se que os termos utilizados para designar o movimento na sociedade são flexíveis, vão sendo modificados ao longo dos anos, ou seja, eles não se estabilizam. Pelo contrário, para demonstrar que a prática está evoluindo juntamente com a sociedade, há uma tendência a ir se alterando as denominações. Assim, o que se institucionaliza são as ações e os arranjos estruturais decorrentes, como o Balanço Social - o que não implica dizer que fiquem estagnados ao longo dos anos. Mas os discursos podem mudar com mais facilidade, pois funcionam como um pano de fundo para o movimento.

Observa-se também que a idéia de co-responsabilização da empresa com o Estado e com outros atores, notadamente o Terceiro Setor, vai se fortalecendo, aumentando então o número e a abrangência dos projetos efetuados em parcerias. Esse discurso, então, vai ganhando espaço e profundidade nas ações e arranjos estruturais dos bancos relacionados à RSE.

Por fim, a análise dos Balanços Sociais dos Bancos/Febraban revela que a RSE no setor bancário está evoluindo para uma ação estruturada e integrada ao negócio, de modo diferente do que ocorria há uma década, indicando a crescente institucionalização da prática social nesse período. 


\section{Referências}

ASSAF NETO, A. Mercado financeiro. 4. ed. São Paulo: Atlas, 2001.

BACEN -Banco Central do Brasil. Relatório Top 50 do Banco Central do Brasil - 50 maiores bancos e o consolidado do SFN, com database em 31-12-2004. Disponível em: <http://www.bcb.gov.br/pre/composicao/bm.asp>. Acesso em: 12 abr. 2005.

BOWEN, H. Responsabilidades sociais do homem de negócios. Rio de Janeiro: Civilização Brasileira, 1953.

BRASIL. Presidência da República. Casa Civil. Lei no 4.595, de 31 de dezembro de 1964.

CALICCHIO, A. C. A. O banco atual (do fim do tradicionalismo à aceitação de uma nova concepção exigida pelo mercado). In: HISTÓRIA das instituições financeiras e sua contribuição ao progresso econômico dos povos. São Paulo: Estrela Alfa Editora, 1972.

CAPPELLIN, P. et al. As organizações empresariais brasileiras e a responsabilidade social. In: KIRSCHNER; GOM ES; CAPPELLIN (Org.). Empresa, empresários e globalização. Rio de Janeiro: Relume Dumará; Faperj, 2002.

CHEIBUB, Z;; LOCKE, R. Valores ou interesses? Reflexões sobre a responsabilidade social das empresas. In: KIRSCHNER; GOM ES; CAPPELLIN (Org.). Empresa, empresários e globalização. Rio de Janeiro: Relume Dumará; Faperj, 2002.

FEBRABAN. Federação Brasileira das Associações de Bancos. Balanço social dos bancos 1993. São Paulo, [1994].

FEBRABAN. Federação Brasileira das Associações de Bancos. Balanço social dos bancos 1994. São Paulo, [1995].

FEBRABAN. Federação Brasileira das Associações de Bancos. Balanço social dos bancos 1995. São Paulo, [1996].

FEBRABAN. Federação Brasileira das Associações de Bancos. Balanço social dos bancos 1996. São Paulo, [1997].

FEBRABAN. Federação Brasileira das Associações de Bancos. Balanço social dos bancos 1997. São Paulo, 1998.

FEBRABAN. Federação Brasileira das Associações de Bancos. Balanço social dos bancos 1998. São Paulo, 1999.

FEBRABAN. Federação Brasileira das Associações de Bancos. Balanço social dos bancos 1999. São Paulo, 2000.

FEBRABAN. Federação Brasileira das Associações de Bancos. Balanço social dos bancos 2000. São Paulo, 2001.

FEBRABAN. Federação Brasileira das Associações de Bancos. Balanço social dos bancos 2001-02. Os bancos e a sociedade. São Paulo, 2002.

FEBRABAN. Federação Brasileira de Bancos. Balanço social dos bancos 2002. Os bancos, seus públicos e a sociedade. São Paulo: [2004a].

FEBRABAN. Federação Brasileira de Bancos. Balanço social dos bancos [relativo a 2003]. São Paulo, [2004b].

MOTTA, P. C. Responsabilidade social das empresas: uma visão operacional. Rio de Janeiro: PUC, 1981. (Documento de trabalho n.17).

PAULA, S. G.; ROHDEN, F. Filantropia empresarial em discussão: números e concepções a partir do estudo do Prêmio ECO. In: LANDIN, L. (Org.). Ações em caridade: militância, caridade, assistência etc. Rio de Janeiro: NAU, 1998.

PELÁEZ, C. M.; SUZIGAN, W. História monetária do Brasil: análise da política, comportamento e instituições monetárias. (Monografia n.23) - Ipea/Inpes, Rio de Janeiro. 1976.

SOUZA, H.. Balanço social: voluntário ou obrigatório? Folha de São Paulo, São Paulo, 7 abr. 1997.

TORRES, C. Responsabilidade social e transparência. Orçamento e Democracia: debatendo políticas públicas - Ibase, Rio de Janeiro, n.10, out. 1998.

TROSTER, R. L. Concentração bancária. Disponível em: <http://www.febraban.org.br/arquivo/servicos/imprensa/conc0404.pdf>. Acesso em: 18 mai 2005.

VENTURA, E. C. F. Responsabilidade social sob a óptica do "Novo espírito do capitalismo". In: ENCONTRO DA ASSOCIAÇÃO NACIONAL DOS PROGRAMAS DE PÓS- GRADUAÇÃO EM ADMINISTRAÇÃO (ANPAD), 27., 2003, Atibaia. Anais... Atibaia: Anpad, 2003. 